\title{
A Review: Different Extraction Techniques of Pectin MDJC Sandarani*
}

Department of Food Science and Technology, Faculty of Livestock Fisheries and Nutrition, Wayamba University of Sri Lanka, Makandura, Sri Lanka

*Corresponding author: MDJC Sandarani, Department of Food Science and Technology, Faculty of Livestock Fisheries and Nutrition, Wayamba University of Sri Lanka, Makandura, Sri Lanka; E-mail: jayanichathurika69@gmail.com

Received date: Aug 21, 2017; Accepted date: Nov 21, 2017; Published date: Nov 27, 2017

Copyright: $\odot 2017$ Sandarani MDJC. This is an open-access article distributed under the terms of the Creative Commons Attribution License, which permits unrestricted use, distribution and reproduction in any medium, provided the original author and source are credited.

\begin{abstract}
Pectin is recently investigated for different applications in food industry, medicinal and pharmaceutical field. Extraction of pectin using different techniques have become a great challenge and yet to be discovered. Recent studies involving extraction of pectin using acids, microwave assisted and enzymes are reviewed, with the aim to capture the state of art on current research about pectin extraction. Extraction techniques have been discussed in related to different acids and enzymes.
\end{abstract}

Keywords: Acids; Enzymes; Extraction; Microwave; Pectin

\section{Introduction}

The complex hetero polysaccharide known as pectin is found in the primary cell wall of dicotyledonous plants and it is extensively employed as a gelling agent, thickener, stabilizer emulsifier and edible coating in food industry. It is made out of D-galacturonic acid, Lrhamnose, L-arabinose and D-galactose. They are linked by a (1 to 4 ) linkages [1-8].

There are two types of pectin depending on their Degree of Methylation (DM), pectin is referred to as high methoxy pectin $(\mathrm{DM}>50)$ or low methoxy pectin $(\mathrm{DM}<50)$. High methoxy pectin can form gels in an acidic medium ( $\mathrm{pH}$ 2.0-3.5) if sucrose is present at a concentration higher than 55 weight $\%$. Low methoxy pectin can form gels over a larger $\mathrm{pH}$ range (2.0-6.0) in the presence of a divalent ion, such as calcium [9].

Recovery of pectin is crucial unit operation in food industry in order to provide adequate supply for the growing demand $[10,11]$. Pectin is extracted at high temperature by hydrolyzing proto pectin in to pectin at commercial level, but there are novel perspectives in pectin production [12-21].

Conventional method is comprised with two main steps, hydrolysis of proto-pectin in to pectin using acids and subsequently precipitated by ethanol [22-24]. However, acid treatments have several draw backs, due to that, novel methods such as Microwave Assisted Extraction, enzymatic extraction, supercritical water extraction and ultra sound extraction have become more popular [25-28]. Microwave Assisted Extraction exhibits large handling capacity, short processing time and good purity. Enzymatic extraction exhibits mild conditions, low energy consumption and no pollution [29-31].

Pectin structure, uses and applications were extensively reviewed [32-34]. However, there are limited review articles based on different extraction techniques of pectin. The main purpose of this article is to highlight about extraction techniques of pectin.

\section{Acid extraction of pectin}

Pectin has been extracted using chemical methods in order to examine the structural features and functional properties of pectin. The chemical agents used for pectin extraction are divided into four groups. They are water and buffers, calcium-ion chelators, acids and bases. Acids are the strongest extracting agents of pectin as they facilitate extraction of insoluble pectin that is tightly bound to the cell matrix of the plant material and result in higher yields [35-37].

Pectin is generally enriched in galacturonic acid. Various studies have shown the effects of acid extractant strength on yield of pectin, chemical, and/or physicochemical characteristics [38]. Most commonly used acids are acetic, citric, lactic, malic, tartaric (organic), hydrochloric, nitric, oxalic, phosphoric and sulfuric acids [39-41].

It has found that an increase in acid strength (that is, decreasing $\mathrm{pH}$ ) plays an important role in increasing the galacturonic acid content. Moreover, acid type and concentration affect the yield, physiochemical and functional properties of pectin [42,43]. In contrast, some of the results of studies are contradictory [44].

Hydrochloric acid shown to be the highest yield of pectin among hydrochloric, nitric and citric acid extracted from guava peel, citrus fruits, banana and cocoa pods. $\mathrm{pH}$ and temperature ranged from 1 to 3 and $60^{\circ} \mathrm{C}$ to $85^{\circ} \mathrm{C}$ sequently [45-48]. Presence of high concentration of hydrogen ions, stimulate the hydrolysis of pectin from proto pectin. Higher ionic strength acids have an improved capability to precipitate pectin due to their higher affinity for cations such as $\mathrm{Ca}^{2+}$ which stabilizes the pectin molecule. However, hydrochloric acid produced pectin with a smaller DM range in which LM pectin [49]. In hot acid media pectin can be degraded rapidly due to high lability and sensitivity for acid. Therefore, Pectin extracted using hot acid is low methoxylated due to demethylation and fragmentation of the polygalacturonic chain. Moreover, LM pectin occurs in a broad $\mathrm{pH}$ range, at most up to $\mathrm{pH} 6$ [50-53].

Nitric acid is also used commonly to acidify hot water in order to extract pectin. The pectin yield increased with increasing extractant strength of nitric acid. The highest yield (10.9\%) was obtained as the extractant strength was increased up to $\mathrm{pH} 1.2$ from cinnamon [54]. 
Sulfuric acid has reported the highest yield for pectin extracted from dragon fruit peels [1] In addition, highest yield were reported for sulfuric acid among hydrochloric, acetic and benzoic acid for Moroccan Orange peels [55]. In contrast, some studies have reported that there is no significant effect of type acid on the yield of pectin from apple [56].

Lowest yield were reported for the citric acid. Some studies had reported that acid type strongly influenced the macromolecular and gelling properties of isolated pectin. It also reported that citric acid is the least pectin degrading (depolymerizing and de esterifying) extracting agent. Citric acid can be used to isolate pectin with better gelling properties. However, some studies suggested the use of citric acid because of its higher yield and better quality than other acids [57,58].

The yield of ambarella pectin extraction varied from $16 \%$ to $22 \%$ dry weight of AIR, depending on the extraction condition used. The highest yields were obtained with Oxalic Acid/Ammonium Oxalate (OAAO) and the lowest with water [59].

\section{Microwave extraction of pectin}

Microwave Assisted Extraction involves dielectric heating of plant molecules through the exposure of microwaves. Dipolar rotation of water is taken place due to the absorbance of microwave energy, which leads to generation of heat inside the plant tissues. Microwave-Assisted Extraction (MAE) has been recently investigated by many researchers and found that it can lead to a considerable increase in the yield and quality of extracted pectin [60-62].

When orange peels are subjected to microwave radiation, there is inactivation of pectin esterase enzyme and destruction of orange skin cells due to rapid heat generation in microwave environment [63]. Since the pectin esterase interacts with the pectic substances in the orange peels and reduces their solubility, their inactivation improves the pectin extraction. Moreover, due to the disintegration of parenchyma cells, there is also increase in specific surface area, which facilitates the water absorption capacity of the plant cell. It has been used to reduce extraction time and energy $[64,65]$.

When increasing the microwave power pectin yield has been increased due to the increase in microwave irradiation energy, the penetration of solvent into the plant matrix can be enhanced and can efficiently deliver to plant cells for pectin extraction. Molecular interaction with the electromagnetic field offers a rapid transfer of energy to the solvent and matrix, allowing the dissolution of components to be extracted. As a polar solvent, water can efficiently absorb microwave energy and leads to efficient heating. Moreover, the microwave irradiation accelerates cell rupture by sudden temperature rise and internal pressure increase inside the cells of plant sample, which promotes the destruction of sample surface and in turns the exudation of pectin within the plant cells into the surrounding solvents and increase [66,67].

The increasing micro wave irradiation energy can enhance the penetration of solvent in to the plant matrix and deliver efficiently to materials through molecular interaction with the electromagnetic field and offer a rapid transfer of energy to the solvent and matrix, allowing the dissolution of components to be extracted.

Water can efficiently absorb microwave energy and leads to efficient heating as it is a polar solvent. Moreover, the microwave irradiation accelerates cell rupture by sudden temperature rise and internal pressure increase inside the cells of plant sample, which promotes the destruction of sample surface and in turns the exudation of pectin within the plant cells into the surrounding solvents and increased the extraction yield [68]. Similarly, optimization of extraction process of pectin from apple pomace using Microwave Assisted Extraction, found to be the highest yield from apple pomace and also lower extraction time when compared to conventional heating [69].

In contrast, there is no any significant difference in yield and quality characteristics extracted from both conventional extraction and Microwave Assisted Extraction except moisture and ash content. Increase in microwave power did not affect yield and quality characteristics of pectin from jackfruit rinds [70].

In addition, pectin extracted using traditional method is not only poor in term of quantity but also quality in which prolonged exposure of pectin to the heat treatment during extraction leads to pectin degradation [71].

\section{Enzymatic extraction}

Plant cell wall is composed of an entangled network of different polysaccharides including pectin. Cell wall degrading enzymes with minimum pectinolytic activity are used to hydrolyze non pectin plant cell wall components in enzymatic extraction of pectin [72,73].

Enzymatic extraction of pectin is environmentally safe and more effective in terms of pectin yield. Different enzymes such as polygalacturonase, hemicellulose, protease and microbial mixed enzymes, cellulose, $\alpha$-amylase, celluclast, alcalase and $\alpha$-amylase and neutrase, Xylase, cellulose, b-glucosidase, endopolygalacturonase and pectinesterase are used in pectin extraction as enzymes have the ability to degrade pectin and modify the physicochemical properties of the pectin [74-82].

\section{Cellulase enzyme}

Cellulase enzyme has been used for isolation of pectin from chicory roots and cauliflower and has shown positive effects towards hydrolyzing of cellulose from the cell wall and releasing of pectin from the cell wall [83].

Use of the cellulase led to the biggest yield and Poly Galacturonic Acid (PGA) content in pectin extracted from pumpkin due to the degradation of the cellulose matrix. Furthermore, pectin was extracted from pumpkin using an enzyme complex which contained cellulase has given the highest yield ( $14 \%$ on dry weight basis) due to degradation of cellulose matrix and other insoluble constituents of the plant cell wall. In contrast, it is believed that it has a pectinesterase activity, which could have an effect on degree of esterification [84].

\section{Polygalacturonase enzyme}

Polygalacturonase have been used to extract pectin from apple and pears and observed a great performance in yield which indicates a higher affinity of the PGI enzyme for this substrate. Yield of pectin was $20 \%$ and $60 \%$ higher than with chemical extraction for apple and pears respectively. These results indicate that pear pomace seems to be a better substrate for pectin enzymatic extraction rather than apple pomace [85].

The commercial enzyme used originates from a selected strain of Aspergillus niger and has mixed activities of pectinlyase, pectinesterase and polygalacturonase. Pectin yield from cladodes is not significantly 
different between enzymatic extraction and classical method. But it offers lower extraction temperature and easier treatment of purification of the effluents [86].

\section{References}

1. Tang PY, Kek TS, Gan CZ, Hee CY, Chong CH, et al. (2011) Yield and some chemical properties of pectin extracted from the peels of dragon fruit Hylocereus polyrhizus (Weber) Britton. The Philippine Agricultural Sciences 94: 307-311.

2. Girma E, Worku T (2016) Extraction and characterization of pectin from selected fruit peel waste. Int J Sci Res 6: 447-454

3. Chan S, Choo W (2013) Effect of extraction conditions on the yield and chemical properties of pectin from cocoa husks. Food Chemistry 141: 3752-3758.

4. Nosálová GL, Prisenžňáková Z, Koštálová A, Ebringerová Z, Hromádková (2011) Suppressive effect of pectic polysaccharides from Cucurbita pepo L. var. Styriaca on citric acid-induced cough reflex in guinea pigs. Fitoterapia 8: 357-364

5. Simpson GA, Morris (2014) The anti-diabetic potential of polysaccharides extracted from members of the cucurbit family: A review. Bioactive Carbohydrates. Dietary Fibre 3: 106-114.

6. Egbekun MK, Nda-suleiman EO, Akinyeye O (1998) Utilization of fluted pumpkin fruit (Telfairia occidentalis) in marmalade manufacturing. Plant Foods for Human Nutrition 52: 171-176

7. Singthong J,Ningsanond S, Cuib SW,Goff HD (2005) Extraction and physicochemical characterization of Krueo Ma Noy pectin, Food Hydrocolloids 19: 793-801.

8. Yoo S, Lee YH, Lee H, Bae IY, Lee HG, et al. (2012) Structura characteristics of pumpkin pectin extracted by microwave heating. Food Chemistry 77: 1169-1173.

9. Kliemann E, Simas KN, Amante ER, Prudencio ES, Teofilo RF, et al. (2009) Original article optimisation of pectin acid extraction from passion fruit peel (Passiflora edulis flavicarpa) using response surface methodology. International Journal of Food Science and Technology 2 476-483.

10. Cristina L, Vriesmann, Teófilo RF, Petkowicz CLO (2012) Extraction and characterization of pectin from cacao pod husks (Theobroma cacao L.) with citric acid. LWT-Food Science and Technology 49: 108-116.

11. Vasco-correa J,Zapata ADZ (2017) Enzymatic extraction of pectin from passion fruit peel (Passiflora edulis $f$. flavicarpa) at laboratory and bench scale. LWT-Food Science and Technology.

12. Tripodo MM (2015) Enzymatic Extraction of Pectin from Opuntia ficusindica Cladodes. Proceedings of VIII IC on Cactus Pear and Cochineal 93: 393-398.

13. Goto M, Machmudah S, Sasakib M, Tanaka M (1979) Utilization of citrus peel by sub-and supercritical fluid technology. pp: 1-4.

14. Tanaka M, Takamizu A, Suetsugu T, Takahashi A, Hoshino M (2010) Hydrothermal conversion of citrus pectin and galacturonic acid into valuable compounds. Proc. 1st Int. Seminar Fundam, Bali. Appl Chem Eng. A011: 1-6.

15. Roy BC, Hoshino M, Ueno H, Sasaki M, Goto M (2007) Supercritical carbon dioxide extraction of the volatiles from the peel of Japanese citrus fruits. J Essent Oil Res 19: 78-84.

16. Terada A, Kitajima N, Machmudah S, Tanaka M, Sasaki M, et al. (2010) Cold-pressed yuzu oil fractionation using counter current supercritical $\mathrm{CO}_{2}$ extraction column. Sep Purif Technol 71: 107-113.

17. Ueno H, Tanaka M, Hoshino M, Sasaki M, Goto M (2008) Extraction of valuable compounds from the flavedo of Citrus junos using subcritical water. Sep Purif Technol 62: 513-516.

18. Ueno H, Tanaka M, Machmudah S, Sasaki M, Goto M (2008) Supercritical carbon dioxide extraction of valuable compounds from Citrus junos seed. Food Bioprocess Technol 1: 357-363.

19. Takahashi A, Takamizu A, Suetsugu T, Tanaka M, Hoshino M (2010) Extraction of valuable compounds from byproduct of citrus juice processing utilizing synergistic effect of water and carbon dioxide. Proc. $1^{\text {st }}$ Int. Seminar Fundam, Bali. Appl Chem Eng A010: 1-5.

20. Wang X, Chen Q, Lü X (2014) Food hydrocolloids pectin extracted from apple pomace and citrus peel by subcritical water. Food Hydrocolloids $38: 129-137$

21. Fukuzato R, Tanaka M, Goto M (2006) Green Solvent processing platform for the extraction of the nutraceutical ingredients from unused biomass-citrus fruits.

22. Djilas S (2009) By products of fruit processing as a source of phytochemicals. Chemical Industry And Chemical Engineering Qartely 15: 191-202.

23. Ibarz A, Llorca M,Paga A (2001) Extraction and characterization of pectin from stored peach pomace. Food Research Interantional 34: 605-612.

24. Kanmani P, Dhivya E, Aravind J, Kumaresan K (2014) Extraction and Analysis of pectin from citrus peels: Augmenting the yield from citrus limon using statistical experimental design. Iranica Journal of Energy and Environment 5: 303-312

25. Jeong H, Kim HY, Ahn SH, Oh SC, Yang I, et al. (2014) Optimization of enzymatic hydrolysis conditions for extraction of pectin from rapeseed cake (Brassica napus L.) using commercial enzymes. Food Chemistry 157: 332-338.

26. Matora AV, Korshunova VE, Shkodina OG, Zhemerichkin DA, Ptitchkina NM, et al. (1995) The application of bacterial enzymes for extraction of pectin from pumpkin and sugar beet. Food Hydrocolloids, 9: 43-46.

27. May CD (1990) Industrial pectins: Sources, production and applications. Carbohydrate Polym 12: 79-99.

28. Yui XC, Sun DL (2013) Microwave and enzymatic extraction of orange peel pectin. Asian journal of Chemistry 25: 5333-5336.

29. Yue XT, Shen AR, Tan ZM, Li CZ (2011) China Oils Fats, 3: 6.

30. Jose MR, Schols HA, Voragen AGJ (1996) Extraction, characterization and enzymatic degradation of lemon peel pectins. Ann Bot 282: 271-284.

31. Liew SQ, Chini NL, Yusof YA, Sowndhararajan (2015) Comparison of acidic and enzymatic pectin extraction from passion fruit peel and its gel properties. Journal of Food Process Engineering 1-11.

32. Baker RA (1997) Reassessment of some fruit and vegetable pectin levels. Journal of Food Science 62: 225-229.

33. BeMiller JN (1986) An introduction to pectins: Structure and properties. ACS Symposium Series. American Chemical Society: Washington.

34. Sharma BR, Naresh L, Dhuldhoya NC,Merchant SU (2006) An Overview on pectins. Times Food Processing Journal 8: 44-51.

35. Assoi S, Konan K, Walker LT, Agbo GN, Dodo H, et al. (2014) Functionality and yield of pectin extracted from Palmyra palm (Borassus aethiopum Mart) fruit. LWT-Food Science and Technology 58: 214-221.

36. Maria B, Gama V, Silvab C, Silvab LM, Abudc A (2015) Extraction and characterization of pectin from citric waste. Chemical Engineering Transactions 44: 259-264.

37. Yapo BM (2007) Food chemistry effect of extraction conditions on the yield, purity and surface properties of sugar beet pulp pectin extracts. Food Chemistry 100:1356-1364.

38. Liew SQ, Chin NL, Yusof YA (2014) Extraction and characterization of pectin from passion fruit peels. Italian Oral Surgery 2: 231-236.

39. Kermani ZJ (2015) Food hydrocolloids functional properties of citric acid extracted mango peel pectin as related to its chemical structure. Food Hydrocolloids 44: 424-434.

40. Min B, Lim J, Ko S, Lee KG, Lee SH, et al. (2011) Bioresource Technology Environmentally friendly preparation of pectins from agricultural byproducts and their structural/rheological characterization. Bioresource Technology 102: 3855-3860.

41. Lim J (2012) Food hydrocolloids extraction and characterization of pectin from Yuza (Citrus junos) pomace: A comparison of conventionalchemical and combined physical e enzymatic extractions. Food Hydrocolloids, 29: 160-165. 
42. Apo B (2009) Biochemical characteristics and gelling capacity of pectin from yellow passion fruit rind as affected by acid extractant. Nature, pp: 1572-1578.

43. Methacanon P, Krongsin J, Gamonpilas C (2014) Food Hydrocolloids Pomelo (Citrus maxima) pectin: Effects of extraction parameters and its properties. Food Hydrocolloids 35: 383-391.

44. Yapo B, Koffi K (2013) Extraction and characterization of highly gelling low methoxy pectin from cashew apple Pomace. Foods 3: 1-12.

45. Banu M, Kannamma GB, Gayatrri P, Nadezhda H, Nandhini J, et al. (2012) Comparative studies of pectin yield from fruits using different acids. Food Science 42: 6349-6351.

46. Bhat SA, Singh ER (2014) Extraction and characterization of pectin from guava peel. Int J Res Eng Adv Tech 2: 1-7.

47. Bhavya DK, Suraksha R (2015) Value added products from agriculture: Extraction of pectin from agro waste product Musa acuminata and Citrus fruit. Res J Agriculture and Forestry Sci 3: 13-18.

48. Israel-Castillo KAT, Baguio SF, Disanta MDB, Lizardo RCM, Dizon EI, et al. (2015) Extraction and characterization of pectin from Saba banana [ Musa " saba "(Musa acuminata x Musa balbisiana) ] peel wastes: A preliminary study. International Food Research Journal 22(1), pp: 202-207.

49. Chan SY, Choo WS (2013) Effect of extraction conditions on the yield and chemical properties of pectin from cocoa husks. Food Chemistry 141: 3752-3758.

50. Mollea C, Chiampo F, Conti R (2008) Extraction and characterization of pectins from cocoa husks: A preliminary study. Food Chemistry 107: 1353-1356.

51. Canteri-Schemin MH, Fertonani HCR, Waszczynskyj N, Wosiacki G (2005) Extraction of pectin from apple pomace. Brazilian Archives of Biology and Technology 48: 259-266.

52. Garna H, Mabon N, Not K, Wathelet B, Paquot M, et al. (2006) Kinetic of the hydrolysis of pectin galacturonic acid chains and quantification by ionic chromatography. Food Chemistry 96: 477-484.

53. Yapo BM, Robert C, Etienne I, Wathelet B Paquot M, et al. (2007) Effect of extraction conditions on the yield, purity and surface properties of sugar beet pulp pectin extracts. Food Chemistry 100: 1356-1364.

54. Besson V, Yapo BM, Koffi K (2013) Cinnamon apple pomace pectins: Physicochemical characteristics and gel-forming properties. J Hum Nutr Food Sci 1: 1018

55. Sayah MY, Chabir R, Madani ELN, Kandri YR, Chadi FO, et al. (2014) Comparative study on pectin yield according to the state of the orange peels and acids used. Int J Innov Res Sci Eng Technol 3: 15658-15665.

56. Yapo BM. (2011) Pectic substances: From simple pectic polysaccharides to complex pectins: A new hypothetical model. Carbohydrate Polymers 86: 373-385.

57. Liew SQ, Chin NL, Yusof YA (2014) Extraction and characterization of pectin from passion fruit peels. Italian Oral Surgery 2: 231-236.

58. Canteri-Schemin MH, Fertonani HCR, Waszczynskyj N, Wosiacki G (2005) Extraction of pectin from apple pomace. Brazilian Archives of Biology and Technology 48: 259-266.

59. Koubala BB, Mbome MI, Kansci G, Mbiapo FT, Crepeau MJ, et al. (2007) PHysicochemical properties of pectins from ambarella peels (Spondias cytherea) obtained using different extraction conditions. Food Chemistry 106: 1202-1207.

60. Mohapatra D, Mishra S (2011) Current trends in drying and dehydration of foods. NOVA Science Publishers Inc, USA. pp: 311-351.

61. Routray W, Orsat V (2012) Microwave-assisted extraction of flavonoids: A review. Food and Bioprocess Technology 5: 409-424.

62. M Kratchanova, I Panchev, E Pavlova, L Shtereva (1994) Extraction of pectin from fruit materials pretreated in an electromagnetic field of super-high frequency. Journal of Carbohydrate Polymers 25: 141-144.

63. Zhongdong L, Guohua W, Yunchang G, Kennedy JF (2006). Image study of pectin extraction from orange skin assisted by microwave. Carbohydrate Polymers 64: 548-552.
64. Kratchanova M, Pavlova E and Panchev I (2004) The effect of microwave heating of fresh orange peels on the fruit tissue and quality of extracted pectin. Carbohydrate Polymers 56: 181-185.

65. Fishman ML, Chau HK, Hoagland PD, Hotchkiss (2006) Microwaveassisted extraction of lime pectin 20: 1170-1177.

66. Maran JP, Prakash A (2015) Process variables influence on microwave assisted extraction of pectin from waste Carcia papaya L. peel. International Journal of Biological Macromolecules 73: 202-206.

67. Kute A, Mohapatra D, Babu B, Sawant BP (2015) Optimization of microwave assisted extraction of pectin from orange peel using response surface methodology. J Food Res Technol 3: 62-70.

68. Maran JP, Sivakumar V, Thirugnanasambandham K, Sridhar R (2013) Optimization of microwave assisted extraction of pectin from orange peel. Carbohydrate Polymers 97: 703-709.

69. Wang S, Chen F, Wu J, Wang Z, Liao X et al. (2007) Optimization of pectin extraction assisted by microwave from apple Pomace using response surface methodology. Journal of Food Engineering 78: 693-700.

70. Liu Y, Shi J, Langrish T (2006) Water-based extraction of pectin from flavedo and albedo of orange peels. Chemical Engineering Journal 120: 203-209.

71. Bagherian H, Ashtiani FZ, Fouladitajar A, Mohtashamy M (2011). Comparisons between conventional, microwave-and ultrasound-assisted methods for extraction of pectin from grapefruit. Chemical Engineering and Processing. Process Intensification 50: 1237-1243.

72. Puri M, Sharma D, Barrow CJ (2012) Enzyme-assisted extraction of bioactives from plants. Trends in Biotechnology 30: 37-44.

73. Fissore EN, Ponce NM, Wider EA, Stortz CA, Gerschenson LN, et al. (2009) Commercial cell wall hydrolytic enzymes for producing pectinenriched products from butternut (Cucurbita moschata, Duchesne ex Poiret). Journal Food Engineering 93: 293-301.

74. Yuliarti O, Merino LM, Kelvin KT, Goh Mawson JA, Charles SB, et al. (2011) Effect of celluclast 1.5 L on the physicochemical characterization of gold kiwifruit pectin. International Journal of Molecular Sciences, pp: 6407-6417.

75. Ptichkinaa NM, Markinaa OA, Rumyantsevab GN (2008) Pectin extraction from pumpkin with the aid of microbial enzymes. Food Hydrocolloid. 22: 192-195.

76. Cui SW, Chang YH (2014) Emulsifying and structural properties of pectin enzymatically extracted from pumpkin. Journal of Food Science 58: 396-403.

77. Fissore EN, Rojas AN, Gerschenson LN, Williams PA (2013) Butternut and beetroot pectins: Characterization and functional properties. Food Hydrocolloids 31: 172-182.

78. Lim J, Yoo J, Ko S, Lee S (2012) Extraction and characterization of pectin from Yuza (Citrus junos) pomace: A comparison of conventionalchemical and combined physical enzymatic extractions. Food Hydrocolloid 29: 160-165.

79. Jeong HS, Kim HY, Ahn SH, Oh SC (2014) Optimization of enzymatic hydrolysis conditions for extraction of pectin from rapeseed cake (Brassica napus L.) using commercial enzymes. Food Chemistry 157: 332-338.

80. Qiu LP, Zhao GL, Wu H (2010) Investigation of combined effects of independent variables on extraction of pectin from banana peel using response surface methodology. Carbohydrates Polymers 80: 326-331.

81. Hwang JK, Kim CJ, Kim CT (1998) Extrusion of apple Pomace facilitates pectin extraction. Journal of Food Science 63: 841-844.

82. Yu XC, Sun DL (2013) Microwave and enzymatic extraction of orange peel pectin. Asian Journal of Chemistry 25: 5333-5336.

83. Panouille M, Thibault JF, Bonnin E (2006) Cellulase and protease preparations can extract pectins from various plant byproducts. Journal of Agriculture and Food Chemistry 54: 8926-8935.

84. Shkodina OG, Zeltser OA, Selivanov NY, Ignatov VV (1996) Enzymic extraction of pectin preparations from pumpkin. Food Hydrocolloids 12: 313-316. 
Citation: Sandarani MDJC (2017) A Review: Different Extraction Techniques of Pectin. J Pharmacogn Nat Prod 3: 143.

doi: $10.4172 / 2472-0992.1000143$

Page 5 of 5

85. Franchi ML, Marzialetti MB, Posel GN, Cavalitto SF (2014) Evaluation of enzymatic pectin extraction by a recombinant polygalacturonase (PGI) from apples and pears pomace of argentinean production and characterization of the extracted pectin. Journal of Food Processing and Technology 5: 352 .
86. Tripodo MM, Occhiuto F, Galati EM, Lanuzza F (2015) Proceedings of VIII ${ }^{\text {th }}$ IC on Cactus Pear and Cochineal. p: 393-398. 